(RESEARCH ARTICLE)

\title{
Phytochemical characterization and antimicrobial studies on four folklore medicinal plants in Semi-Arid Region of Borno State, Nigeria
}

Gana Benisheikh Ali Abba 1, ${ }^{*}$, Tom Isyaka Mohammed 2, Jibrin Mallam Wali 3, Mshelia Madu Adamu 4, Kime Mahammed Mahmud 5, Adam Fatima Barma ${ }^{6}$ and Bizi Amina Garba ${ }^{7}$

\author{
${ }^{1}$ Dept of Applied Microbiology and Biotechnology, University of Wolverhampton, United Kingdom/Biotechnology Centre, \\ University of Maiduguri, Borno State. \\ ${ }^{2}$ Dept of Medical Laboratory Science, University of Maiduguri, Borno State, Nigeria. \\ ${ }^{3}$ National Research Institute for Chemical Technology (NARICT, Kano Out station), Kano State, Nigeria. \\ ${ }^{4}$ Dept. of Biological sciences, Fac. of science, Abubakar Tafawa Balewa University, Bauchi state, Nigeria. \\ ${ }^{5}$ Dept. of Biological sciences, Yobe State University Damaturu, Yobe State, Nigeria. \\ ${ }^{6}$ College of Health and Technology Maiduguri/ Centre for Biotechnology, University of Maiduguri, Borno State, Nigeria. \\ ${ }^{7}$ National Biotechnology Development Agency (Bioresources Unit) \& Biotechnology Centre, University of Maiduguri, \\ Borno State, Nigeria.
}

Publication history: Received on 23 February 2020; revised on 05 July 2020; accepted on 06 July 2020

Article DOI: https://doi.org/10.30574/wjarr.2020.7.1.0050

\begin{abstract}
Crude leave extracts of four folklore medicinal plants were subjected to phytochemical screening and antimicrobial assays against microbial pathogens using well diffusion method. The preliminary phytochemical investigation of the crude leave extracts of four folklore consists of Neem, Moringa, Jatropha and Balanites revealed that there is present of bioactive phytocomponents with potential antimicrobial ingredients when Soxhlet extraction was performed using different solvents (Hexane, Chloroform, Methanol, acetone and Ethyl acetate). The crude extracts showed significant antimicrobial activities against all microbial pathogens screened with highest activity in methanol and chloroform extracts of alkaloids as phytocomponents. While highest activity was recorded in methanol and chloroform extracts, faintly in ethyl acetate extracts using phenolics Phytochemical. Whereas, microbial activities was moderately present in chloroform, acetone and ethyl acetate extracts using steroids and reducing sugars phytocomponents respectively. Whereas, the antimicrobial activities against pathogens revealed remarkable sensitivity with prominent zone of inhibitions with ranging from $14 \mathrm{~mm}$ to $26 \mathrm{~mm}$ against Pseudomonas aeruginosa and $10 \mathrm{~mm}$ to $24 \mathrm{~mm}$ in streptococcus species using extracts from chloroform, ethyl acetate, Hexane and methanol extracts. Likewise, moderate zone of inhibition ranging from $14 \mathrm{~mm}$ to $17 \mathrm{~mm}$ was recorded in Staphalococcus aureus, $10 \mathrm{~mm}$ to $17 \mathrm{~mm}$ was recorded in $\mathrm{P}$. pyogene and $10 \mathrm{~mm}$ to $16 \mathrm{~mm}$ in Escherichia coli respectively. Whereas weak zone of inhibition ranging from $10 \mathrm{~mm}$ to $12 \mathrm{~mm}$ was obtained against streptococcus mutans. The bioactive ingredients of those with antimicrobial activities are screened and recommended that more research work be conducted to explore their bioactive components for formulation into appropriate dosage as potential antibiotics for the treatment of infectious diseases in the study area.
\end{abstract}

Keywords: Folklore, Phytochemical, Characterization, Antimicrobial studies, Semi-arid, Borno state, Nigeria

\section{Introduction}

Traditional medicine as a source of bioactive compound for pharmaceutical and microbiological studies has been handed down from generation to generation for thousands of years [1,2]. In recent years medicinal plants and their phytocomponents are used in traditional treatments of various diseases in the developing countries like Nigeria because of the high cost of modern synthetic drugs [3]. Furthermore, the bioactive components of herbal plants appear to be rewarding as it might lead to the development of phytomedicine which are safe, effective and inexpensive [4]. According

\footnotetext{
* Corresponding author: Gana Benisheikh Ali Abba
} 
to [2] traditional herbal medicine is an important component of primary health care system in developing countries. Several benefits are derived from plant secondary metabolite, pharmaceuticals and antimicrobial efficiency which would play a prominent role against microbes. Hence, phytochemical survey and screening of medicinal plants used by different ethnic group and agroclimatological zone has become inevitable to explore the potential source for characterization of bioactive compounds [5]. Recent studies revealed that numerous plants and herb species has been a source of medical agents with potential antimicrobial and antiviral properties [6,7]. Several surveys have been reported in the developing countries that there has been an increasing incidence of multiple antibiotics resistances in pathogenic microorganisms $[8,9]$. The indiscriminate use of synthetic antimicrobial drugs commonly employed in the treatment of ailment lead to antibiotic resistance. This necessitate scientists to explore for new antimicrobial substance from various sources such as herbs and medicinal plants [10,11]. According to [12,13] some traditional healing system have already produced bioactive compounds from phytocomponents that are efficient and effective against antibioticresistant strains of bacteria. Earlier studies on medicinal plants have showed that almost every component of the seeds, leaves, roots, bark, trunk and branches with potential medicinal properties are used in the semi-arid regions since time immemorial [14]. Thus, the phytocomponents of plants enhances ethnobotanical and pharmacological studies leading to production of a more potent drug with high antimicrobial agent with less side effect $[15,16]$. In the present research work four folklore medicinal plants were evaluated for phytochemical and antimicrobial properties.

\section{Material and methods}

\subsection{Sample collection}

The fresh leaves of four folklore medicinal plant parts of Neem, Moringa, Jatropha and Balanite were collected randomly from the semi-arid region of Borno State. The plants were identified according to various literature and other pertinent taxonomic. The leaves were washed under running tap water to eliminate dust and other foreign particles. The collected leaves were chopped into pieces and coarsely powdered with suitable homogenizer.

\subsection{Preparation of extracts}

The powdered sample obtained after homogenization were subjected to phytoextraction with organic solvents using methanol, ethyl acetate, chloroform and Hexane by using Soxhlet extraction. The extracts were collected and distilled off on a water bath at atmospheric pressure. The residues were used with the appropriate solvents for the phytocomponents screening and antimicrobial studies. Phytochemical characterization of medicinal plant (Neem, moringa, balanite and jatropha) leaves extracts were conducted by extraction, isolation and identification of phytocomponents. Bioactive ingredients like alkaloids, flavonoids, phenolics, reducing sugar and fatty acids were determined using Soxhlet extraction procedure as described by [18].

\subsection{Antimicrobial assay}

Antimicrobial activity of the different medicinal plants extract was determined for various phytocomponents and bioactive compound responsible for antimicrobial sensitivity by adapting [19]. The microorganisms were cultured on Muller Hinton agar medium and incubated at $37^{\circ} \mathrm{C}$ for 24 hours, the diameter of the Zone of inhibition was recorded in MM and susceptibility is determined by comparing with standard values [20].

\subsection{Phytochemical screening}

Phytochemical screening of crude leaves extract of the four folklore medicinal plants as described by Harborne, [21].

\subsubsection{Detection of Alkaloids}

Alkaline Reagent Test: Each plant extracts were treated with few drops of Sodium hydroxide solution. Formation of intense yellow colour after addition of dilute HCL acid indicates the presence of flavonoids as described by [22].

\subsubsection{Detection of phytosterols}

Liebermann Burchard's test: the plant extracts were treated with chloroform and filtered. The filtrates were treated with few drops of acetic anhydride, boiled and cooled. Concentrated sulphoric acid were added, formation of brown ring at the junction indicates the presence of phytosterols [23].

\subsubsection{Detection of reducing sugars}

The plant extracts were dissolved individually in $5 \mathrm{ml}$ distilled water and filtered; the filtrates were used to test for the presence of carbohydrates. 
Fehling's Test: filtrates were hydrolyzed with dil. HCL, neutralized with alkali and heated with Fehling's A\&B solutions. Formation of red precipitate indicates the presence of reducing sugars.

\subsubsection{Detection of Tannins}

Lead acetate test: the plant extracts were dissolved separately in distilled water and to each $10 \%$ lead acetate solution were added. The appearance of yellow precipitate confirmed the tannins [24].

\subsubsection{Detection of Saponins}

Froth Test: the plant extracts were diluted individually with distilled water up to $20 \mathrm{ml}$ and shaken in a graduated cylinder for 15 minutes. Formation of $1 \mathrm{~cm}$ layer of "Honey comb" froth indicates the presence of Saponins as described by [22].

\section{Results and discussion}

The presence of antimicrobial substances in the plants and herbs for the treatment of illness begins since times immemorial [14]. The extracts are potential sources of novel antimicrobial and phytomedicine compounds due to the presence of bioactive phytocomponents that produce a definite physiological action on human body [25]. In this studies, the bioactive phytocomponents of four folklore medicinal plants used for the treatment of illness in semi-arid region of Borno state as shown in (Table 1).

Table 1 List of the four folklore medicinal plants used in the experiment with their phytochemical assays and therapeutic properties.

\begin{tabular}{|c|c|c|c|c|c|}
\hline $\begin{array}{l}\text { Scientific } \\
\text { Name }\end{array}$ & $\begin{array}{l}\text { Common Name/ } \\
\text { vernacular }\end{array}$ & $\begin{array}{l}\text { Plant part } \\
\text { used }\end{array}$ & Family & Phytochemical Assay & Therapeutic properties \\
\hline $\begin{array}{l}\text { Azadirachta } \\
\text { Indica }\end{array}$ & $\begin{array}{l}\text { Neem/Dogon } \\
\text { yaro }\end{array}$ & Leaves & Meliaceae & $\begin{array}{l}\text { Phenols, unsaturated } \\
\text { sterols, } \\
\text { polysaccharides [27]. } \\
\text { Flavoids, triterpenes } \\
\text { and saponine, } \\
\text { diterpenoids, } \\
\text { limonoids [26,18] and } \\
\text { [28]. }\end{array}$ & $\begin{array}{l}\text { Possess anti- } \\
\text { inflammatory and } \\
\text { immunomodulatory } \\
\text { activities. Others include } \\
\text { anticoagulation and } \\
\text { fibrinolytic activities. } \\
\text { Useful in earache boils, } \\
\text { used as a gargle in } \\
\text { stomatitis and gums. }\end{array}$ \\
\hline $\begin{array}{l}\text { Jatropha } \\
\text { curcas }\end{array}$ & $\begin{array}{l}\text { Physic } \\
\text { nut/Gongolon }\end{array}$ & $\begin{array}{l}\text { Seed } \\
\text { extract }\end{array}$ & Euphorbiacae & $\begin{array}{l}\text { Saponine, phenols, } \\
\text { fatty acids [29; 30). } \\
\text { Steroids, tannin } \\
\text { mucilages\&gum. } \\
\text { Diterpenes, } \\
\text { Coumarins, lignanes, } \\
\text { triterpenes, } \\
\text { phytosterols (31). }\end{array}$ & $\begin{array}{l}\text { Possess anatural } \\
\text { antioxidant with broad } \\
\text { spectrum. } \\
\text { inflammation, Local } \\
\text { spasmodic, rheumatism. } \\
\text { Some inhibitory activities } \\
\text { on aspergillus species. }\end{array}$ \\
\hline $\begin{array}{l}\text { Moringa } \\
\text { oleifera }\end{array}$ & $\begin{array}{l}\text { Horse radish/ } \\
\text { Zogole/Allam }\end{array}$ & Leaves & Moringaceae & $\begin{array}{l}\text { Benzyl-isothiocyanate, } \\
\text { presence of alkanoids, } \\
\text { essential oils, } \\
\text { lipophilic } \\
\text { flavoids[32,33]. }\end{array}$ & $\begin{array}{l}\text { Possess basic medicinal } \\
\text { agents for analgesic and } \\
\text { antibacterial [34]. Also } \\
\text { use for treatment of } \\
\text { stomach pain. }\end{array}$ \\
\hline $\begin{array}{l}\text { Balanitesae } \\
\text { gyptiaccus }\end{array}$ & $\begin{array}{l}\text { Desrt } \\
\text { date/Aduwa/Bet } \\
\text { to }\end{array}$ & Leaves & Balanitaceae & $\begin{array}{l}\text { Xylopranosyl } \\
\text { derivatives of soponin } \\
{[35] \text { and }}\end{array}$ & $\begin{array}{l}\text { It contains vermicidal } \\
\text { ingredient and show } \\
\text { significant anthelminthic } \\
\text { activity }\end{array}$ \\
\hline
\end{tabular}

The medicinal actions of plants against specific diseases unique to a particular plant species or group, consistent with phytocomponent, bioactive and secondary metabolites in plant are toxonomical distinct $(18,26]$. The results of the preliminary phytochemical screening (table 2) shows the presence of ingredients such as alkanoids, flavonoids, phenolic compounds, terpenoides, chloroform ethyl acetate and water extracts using method described by [17]. The 
medicinal plants such as Neem, Moringa, Jatropha and balanite are being used traditionally for the treatment of several illness such as carminative, cough, inflammation, wound healing, rheumation and immune-modulatory activities [6,14]. Chloroform and methanol extracts revealed the presence of alkanoids, phenolics in higher concentration, while steroids and reducing sugar in moderate concentration in acetone ethyl acetate and chloroform. While Tanins and phenol faintly present Ethyl acetate extract showed the faintly presence of alkanoids, flavonoids, phenolics, steroids. While fatty acids were completely absent, the result of the antimicrobial property of various extracts against different pathogenic microorganisms were shown in table 3. This investigation revealed that the leaf extract of Azadirachta indica and jatropha carcus possess highly appreciable antimicrobial activity against pseudomonas aerogenisa, with faintly antimicrobial activity in Moringa oleifera and balanite aegyptiaca leaf extracts. While staphylococcus aureus possesses moderate antimicrobial activity in Azadirachta indica and faintly in jatropha carcus. And no antimicrobial activity in both moringa oleifera and balanite aegyptiaca respectively. Whereas, higher antimicrobial activity against all microbes examined were recorded. While, in salmonella species and faintly antimicrobial activity in all plant extracts against streptococcus mutans, streptococcus pyogene and Escherichia coli respectively.

Table 2 Preliminary studies of phytochemical analysis using different solvents

\begin{tabular}{|c|c|c|c|c|c|c|}
\hline Phytocomponents & Hexane extract & $\begin{array}{l}\text { Chloroform } \\
\text { extract }\end{array}$ & $\begin{array}{l}\text { Methanol } \\
\text { extract }\end{array}$ & $\begin{array}{l}\text { Acetone } \\
\text { extract }\end{array}$ & $\begin{array}{l}\text { Ethyl acetate } \\
\text { extract }\end{array}$ & $\begin{array}{l}\text { Water } \\
\text { extract }\end{array}$ \\
\hline Fatty acids & - & - & - & - & - & - \\
\hline Alkanoids & - & +++ & +++ & - & - & + \\
\hline Flavonoids & - & - & - & - & + & + \\
\hline Phenolics & - & +++ & +++ & - & + & + \\
\hline Tannins & - & - & - & - & + & - \\
\hline Steroids & - & ++ & - & ++ & ++ & + \\
\hline Reducing sugars & - & ++ & - & ++ & ++ & - \\
\hline
\end{tabular}

Table 3 Antimicrobial property of various extracts against different pathogenic micro

\begin{tabular}{|c|c|c|c|c|}
\hline \multirow[t]{2}{*}{ Test organism } & \multicolumn{3}{|c|}{ Name of the plants } & \multirow[b]{2}{*}{ Balanites aegyptiaca } \\
\hline & Azadirachta indica & Moringa oleifera & Jatropha curcas & \\
\hline P. aeruginasa & +++ & + & +++ & + \\
\hline S. aureus & ++ & - & + & - \\
\hline E. coli & + & + & + & + \\
\hline S. pyrogene & + & + & + & + \\
\hline S. mutans & + & + & + & + \\
\hline S. species & +++ & +++ & +++ & +++ \\
\hline
\end{tabular}

Table 4 Antimicrobial activity (zone of inhibition) of different phytochemical components of leave extracts

\begin{tabular}{|c|c|c|c|c|}
\hline $\begin{array}{l}\text { Name of the } \\
\text { organism }\end{array}$ & $\begin{array}{l}\text { Chloroform } \\
50 \mathrm{mg} / \mathrm{ml}\end{array}$ & $\begin{array}{l}\text { Ethyl acetate } \\
50 \mathrm{mg} / \mathrm{ml}\end{array}$ & $\begin{array}{l}\text { Hexane } \\
50 \mathrm{mg} / \mathrm{ml}\end{array}$ & $\begin{array}{l}\text { Methanol } \\
50 \mathrm{mg} / \mathrm{ml}\end{array}$ \\
\hline P. aeruginasa & 14 & 16 & 18 & 26 \\
\hline S. aureus & 17 & 14 & 14 & 16 \\
\hline E. coli & 16 & 12 & 10 & 10 \\
\hline S. pyrogene & 14 & 10 & 10 & 17 \\
\hline S. mutans & 12 & 12 & 12 & 10 \\
\hline S. species & 24 & 10 & 10 & 22 \\
\hline
\end{tabular}




\section{Conclusion}

The four folklore plant extracts are potential sources of novel antimicrobial and phytomedicine compounds due to the presence of bioactive phytocomponents that produce a definite physiological action. The bioactive ingredients of those with antimicrobial activities are screened and recommended that more research work be conducted to explore their bioactive components for formulation into appropriate dosage as potential antibiotics for the treatment of infectious diseases in the study area.

\section{Compliance with ethical standards}

\section{Acknowledgments}

The authors would like to acknowledge the immense contribution laboratory staff of microbiology in University of Maiduguri, Borno state for their technical assistance.

\section{Disclosure of conflict of interest}

The authors declare that they have no conflict of interest

\section{References}

[1] Poonam P, Himani B and Shivangi M. (2013). Azadirachtaindica (Neem) antibacterial effects against Escherichia coli and Salmonella. Guru Drone journal of pharmacy and research, 18-21.

[2] Sowjanya KM, K Narendra, J Swathi and A Krishna Satya. (2013). PhytochemicalExtraction and Antimicrobial Efficiency of crude leaf extract of medicinal plant cascabelathevetia. International Journal of Research in pharmaceutical and Biomedical sciences, 4(92).

[3] Hutchings A and Van Staden J. (1994). plant used for stree-related ailments in traditional Zulu, Xhora and sotho medicine; part 1 plants used for headches, J Ethanopharmacol, 43, 89-124.

[4] Shelf LA. (1983). Antibacterial effects of species. J food safety, 6, 29-44.

[5] Krishnaraju AV, Tayi Rao VN, Sundararaju D, Vanisree M, Tsay Hs and Subbaraju GV. (2006). Biological screening of medical plants collected from eastern ghats of india using Artemia salina (Brine shrimp test int. J appl sci eng, $2,115-25$.

[6] Zaika LL. (1998). Species and herbs: The microbial activity and its determination. J food safety, 9, 97-118.

[7] Basile A, Sorbo S, Giordano S, Ricciardi I, Ferrara S, Montessano D, Castaldo Cobianchi R, Vuotto ML. Ferrara L. (2000). Antibacterial and allelopathic activity of extract from Castanea sativa leaves. Fitoterapia, 71, $110-116$.

[8] Westh H, Zinn CS, Rosdahl VT, Sarisa study group. (2004). An antimicrobial consumption and resistance in staphalococcus aureus isolates from 15 hospital in 14 countries. Microbial Drug resistance, 10, 169-176.

[9] Afolayan AJ. (2003). Extracts from the shoots of Arctotisartotoides inhibit the growth of bacteria and ungi. Pharm. Biol, 41, 22-25.

[10] Jigna P and Sumitra C. (2007). Antibacterial and phytochemical studies o Twelve species of Indian medicinal plants. African Journal of Biomedical research, 10, 175-181.

[11] Iwu MM. (2002). In: therapeutic agents from Ethnomedicine. Ethnomedicine and drug discovery. Iwu M.M, wootton JC (Eds) Elsevier science, Amsterdam.

[12] Okpekon T, Yolou S, Gleye C, Robbot F, Loiseau P, Bories C, Grellier F, Frappier F, Laurens A and Hocquemiller R. (2004). Antiparasitic activities of Medicinal plant used in Ivory Coast. J Ethnopharmacol, 90, 91-97.

[13] Kone WM, Kamanzi Atindehou K, Terreaux C, Hostettmann K, Traore D and Dosso M. (2004). Traditional medicine in North Cote-d' Ivoire screening of 50 medicinal plants for antibacterial activity. J. Ethnopharmacol, 93, 43-49.

[14] Benisheikh AAG, Muhammad FM, Kelluri H et.al. (2019). Phytochemical extraction and antimicrobial studies on crude leaf extract of Azadirachtaindica (neem) in semiarid region of Borno state, Nigeria. International Journal of Research and Review, 6(12), 516-522. 
[15] Ebana RUB, Madunagu BE, Ekpe ED and Otung IN. (1991): microbiological exploitation of cardiac glycoside and alkaloids from Garcinia kola, Borreriaocymoides, Kola nitida and Citrus aurantifolia. J. appl. Biotech, 71, 398-401.

[16] Manna A and Abalaka ME. (2000). preliminary screening of the various extracts of physalis angulate (L) for antimicrobial activities, spectrum J, 7, 19-125.

[17] Harbon. (1998). Phytochemical methods, chapman and Harborn.

[18] Bishnu j, Govind ps, Buddha BB, Megh RB, Dinitasharma KS, Janardhan P and Rajani M. (2011). Phytochemical extraction and antimicrobial properties of different medicinal plants: Ocimum sanctum (Tulsi), Eugenia Caryophylata (Clove), Achyranthesbiodentata (Datiwan) and Azadirachtaindica (Neem). Journal of microbiology and Antimicrobials, 3(3), 1-7.

[19] Bauer AW, Kirby WM, Sherris JC and Turck M. (1966). Antibiotic susceptibility testing by a standardized single disc method. Arican journal of clinical pathology, 45, 493-496.

[20] Cowan MM. (1991). Plants products as antimicrobial agents. Olin. Micro. Res, 12(4), 564-582.

[21] Harborne JB. (1998). A guide to modern techniques of plant analysis. USA: Kluwer Academic publshers.

[22] Siddiqui AA and Ali M. (1997). Practical pharmaceutical chemistry. 1sted,. CBS publishers and distributors, New Delhi, 126-131.

[23] Evans WC. (2002). Trease and Evans pharmacognosy. 5th ed., Harr court Brace and company, 336.

[24] Lyengar MA. (1995). Study of crude Drugs. 8thed,. Manipal power press, manipal, India, 2.

[25] S Susmitha, KK Vidyamol, P Ranganayaki and R Vijayaragavan. (2013). phytochemical extraction and antimicrobial properties of Azadirachtaindica (Neem). Global journal of pharmacology, 7(3), 316-320.

[26] Parekh J, Jadeja D and Chanda S. (2005). Efficacy of aqueous and methanol extracts of some medical plants for potential antibacterial activity. Turkey J. Biol, 29, 203-210.

[27] Biswas K, I Chattopadhyay and RK Banerjee. (2002). Biological activities and medicinal properties of neem (Azadirachtaindica) Bandopadhyay, U., curr sci, 82, 1336-1345.

[28] AM El-mahmood, OB Ogbonna and M raji. (2010). the antibacterial activity of Azadirachtaindica (Neem) associated with eye and ear infections, Journal of medicinal plant research, 4(14), 144-1421.

[29] Akbar E, Yaakob Z, Kamarudin S and Ismail M. (2009). Characteristics and composition of Jatropha curcas oil seed from Malaysia and its potential as Biodiesel feedstock. Eur. J. scientific Res, 29, 396-403.

[30] Aqil F, Ahmad I and Mehmood Z. (2006). Antioxidant and free radical scavenging properties of twelve traditionally used Indian medicinal plants. Turk. J. Biol, 177-183.

[31] Naengchomnong WW, Thebtaranonth Y, Wiriyachitra P, Okamoto KT and Clardy J. (1986). Isolation and structure determination of four novel diterpenes from jatropha curcas tetrahedron left, 27, 2439-42.

[32] Bukill HM. (1995). The useful plants of west tropical Africa (2ndedn, vol. 3). Families E.I. Royal Botanical Gardens: Kew, 636.

[33] Tsuchiya H, Sato M, Linuma M, Yokoyama J, Ohyama M, Tanaka T, Takase I and Namikawa I. (1994). Inhibition of the growth of carcinogenic bacteria in vitro by plant flavonones. Experimentia, 50, 846-849.

[34] Stray F. (1998).The natural guide to medicinal herbs and plants. Tiger books international: London, 12-16.

[35] Staerk D, Chapagain BP, Lindin T, Wiesman Z and Jaroszewski JW. (2007). Structural analysis of coplex saponins of Balanitesegyptiaca by 800 MHz 1 H NMR spectroscopy. MagnReson chem, 44, 923-8.

\section{How to cite this article}

Gana BAA, Tom IM, Jibrin MW, Mshelia MA, Kime MM, Adam FB and Bizi AG. (2020). Phytochemical characterization and antimicrobial studies on four folklore medicinal plants in Semi-Arid Region of Borno State, Nigeria. World Journal of Advanced Research and Reviews, 7(1), 01-06. 